
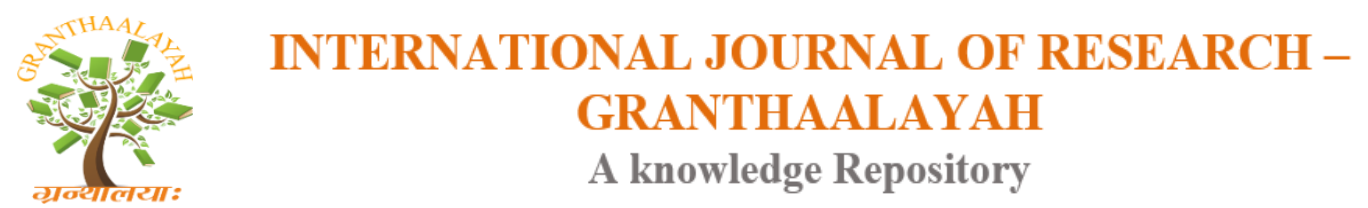

DOI: 10.5281/zenodo.1186214

Science

\title{
THE INFLUENCE OF FISH MORTALITY ON THE FRESHNESS OF FISH
}

\author{
Eddy Suprayitno ${ }^{* 1}$ \\ ${ }^{* 1}$ Lecturer, Faculty of Fisheries and Marine Sciences Brawijaya University, Malang, Indonesia
}

\begin{abstract}
Fish is one of the freshly prepared high-protein foodstuffs. Fish protein needs by the body to speed up the digestion process by the similar function as human proteins. Protein has a function as growth, regulatory and former energy. Moreover, fish is the perishable product which is easy to spoil and cause decreasing quality. One of the factors that the caused the decreasing quality of fish is death method. Where fish that the long process of decay death proved more rapid than the fish that quickly intervening died calmly. This research was conducted to investigate the effect of fish mortality on the old phase of deterioration in fish quality. The method was used in this experiment was Completely Randomized Design (CRD) with 6 treatments rooms is left alone, the medulla oblongata stabbed, beaten hard objects, broken spine, given freshwater ice, and smeared with kluwak. The result showed that there was no significant effect $(\mathrm{P}>0.05)$ on the phase of deterioration of fish quality. Which is the longest phase of fish deterioration in the treatment of fish stabbed medulla oblongata with an average value of 2137.8 minutes.
\end{abstract}

Keywords: Process of Mortality; Level of Freshness; Fish Nila.

Cite This Article: Eddy Suprayitno. (2018). "THE INFLUENCE OF FISH MORTALITY ON THE FRESHNESS OF FISH.” International Journal of Research - Granthaalayah, 6(2), 80-85. https://doi.org/10.5281/zenodo.1186214.

\section{Introduction}

Fish is a food that has many benefits; it is because the fish has high protein content. According to Suprayitno (2016), Protein is needed by the human fish because apart more easily digested also contains amino acids with a pattern similar to the pattern of amino acid found in the human body. Proteins useful for humans for growth and energy production.

Fishery products also have the disadvantage of fast decay and deterioration. The process of degradation and freshness of the fish is strongly influenced by internal factors and external factors. Internal factors include the type and size of the fish, bacteria, and enzymes contained in the body of the fish and their oxidation that occurs in the body of the fish. The external factors include ways of catching and handling fish (Jayanti et al., 2012). 
According to Liviawaty and Afrianto (2014), rottenness fish is divided into 3 phases which prerigor, rigor mortis and rigor mortis post. This phase change can be used as an indicator of changes in the quality of the fish. In the phase of pre-rigor and rigor mortis fish can still be categorized as a fresh product. Changes experienced by fish caused by enzymatic activity, oxidation and microbiological. Before the phase of post-rigor mortis, changes in fish caused by enzymatic activity. Fish that spend a lot of energy before dying, its $\mathrm{pH}$ will be quickly dropped and activates the enzyme that is able to decipher katepsin compounds that are volatile. While the contents of the stomach is a source of bacteria that are able to break down proteins into amino acids (Munandar et al.,2009). Changes caused by oxidation and microbiological take place after entering the phase of post-rigor mortis. Many parameters can be used to determine the freshness of fish both in physical, chemical, biological and organoleptic. The $\mathrm{pH}$ value is a parameter that can be used to determine the level of freshness of fishery products. Based on the $\mathrm{pH}$, can be determined whether the fish meat is still in the phase of rigor mortis or have already entered the phase of post-rigor mortis.

How fish death during arrest have great influence on the stems and the end of the rigor mortis that concentrates on the quality and durable power of fish. Death of fish through a great struggle in every technical arrest, rough handling of fish resulted in injuries, shortens durable and degrade (Reo, 2010).

In Indonesia, efforts to maintain the quality of fresh fish products is still often a major constraint in the industry and exporters of fishery products. Therefore, it is a necessary study on the effect of the manner of death to the level of freshness of the fish.

\section{Materials and Methods}

This study was conducted in July to August 2017 in the Laboratory Engineering Laboratory of Fishery and Hydrobiology, Faculty of Fisheries and Marine Sciences, University of Brawijaya, Malang, Indonesia.

\subsection{Samples}

Materials used in this study include Nila, distilled, kluwak, freshwater ice, a buffer solution, label paper, water, tissue and plastic.

\subsection{Research Design}

The research method used in this research is the experimental method. According to Nazir (2005), experimental research is research done by holding the manipulation of objects. Experimental research is observation under artificial conditions (artificial condition) in which the condition is created and governed by the researcher. In this study conducted preliminary research and primary research. with a completely randomized design (CRD) is simple with 6 treatments manner of death are different ie P1 (left to die alone), P2 (punctured medulla oblongata), P3 (broken vertebrae), P4 (or iced freshwater), P5 (smeared kluwak) and P6 (hit hard objects). Wherein for each treatment be repeated 5 times. 


\subsection{Statistical Analysis}

Data were analyzed diversity Analysis of variance (ANOVA) and if there are significantly different results then do Tukey test at 5\% level with the statistical package for social science (SPSS) version 16.

\section{Implementation of the Research}

The study was conducted using Nila as much as 4 heads for each treatment. Then four fish be labeled in order to distinguish in each phase, the phase of pre-rigor, rigor mortis, rigor, and fish post timing reference. In fish timeframes long awaited and is calculated each phase of fish quality deterioration by using a stopwatch and record the result. In addition to the measured length of time, each phase is also carried out measurements of $\mathrm{pH}$ and physical observation of the organoleptic fish.

$\mathrm{PH}$ analyzes performed on stage when the fish has entered the phase of pre-rigor, rigor mortis, and post-rigor, namely by cutting the fish meat with a knife and weighed on digital scales as much as 1 gram, then crushed samples using a mortar and pestle. The fish meat each phase incorporated into the film and added a bottle of distilled water in the ratio 1: 10. Then the $\mathrm{pH}$ of the meat of each phase is measured by using a $\mathrm{pH}$ meter. the $\mathrm{pH}$ of the sample was measured using a $\mathrm{pH}$ meter that had been calibrated beforehand using a buffer of $\mathrm{pH} 4$ and $\mathrm{pH}$ 7. Into a 100 $\mathrm{ml}$ sample is immersed electrode $\mathrm{pH}$ meter and wait until the number of the readings become stable. $\mathrm{pH}$ was measured twice and the average was calculated.

The freshness of the level measurement in addition to measuring the $\mathrm{pH}$ of fish can also be seen in organoleptic. Fish in the phase of pre-rigor, rigor mortis and rigor observed organoleptic post. Organoleptic observations include several parameters, namely the state of the eyes, gills, lenders body surface, bacon, smells, and textures.

\section{Results and Discussion}

The results of ANOVA showed that at the level of $5 \%$ is obtained $\mathrm{F}$ arithmetic $<\mathrm{F}$ table which means that the treatment means the fishing mortality giving effect did not differ significantly on the level of freshness of the fish, then followed by a further test of Tukey to determine whether there are differences in each treatment. Graph long phase of Nila quality deterioration can be seen in Figure 1.

From the below graph, it can be seen that quality deterioration time of the longest fish of 6 treatments used is in treatment P2 (punctured medulla oblongata). According Reo (2010), which led to declining fish quality is the way of death. Where the fish are struggling to spend energy to die proved more perishable than a dead fish fast stride. Because it is obvious that the fish were quickly killed fresher than the old fish die. When after the death of fish there is a change of $\mathrm{pH}$ in fish flesh is very large role because it affects the process of glycolysis and attack bacteria, the speed of decline in the value of $\mathrm{pH}$ in fish because fish die flounder and spend a lot of energy so that the glycogen stores are available on the meat continues to decrease (Munandar et al., 2009). At the time dead fish will quickly change ATP to ADP by the enzyme ATP-ase, then converted 
into AMP by the enzyme myokinase. Changes AMP into IMP met by deaminase enzymes, then of IMP into inosine influenced by the phosphatase enzyme. IMP (inosinate acid) known as a giver of sweetness in the flesh of the fish. Flavor produced by the inosinate acid is the effect of the combination with glutamic acid (Nurjanah et al., 2004). According to Nurjanah et al., 2011, when the dead fish turned into anaerobic conditions and ATP is broken down by enzymes in the body to release energy. Along with this, there was a biochemical process that causes the part of the muscle protein (actin and myosin) to contract so that the fish's body became rigid. Along with this also, carbohydrate on glycogen-shaped fish meat decomposes to produce lactic acid at the end of glycolysis. The lactic acid can lower the $\mathrm{pH}$ in fish and suppress the activity of microbes that can slow down the process of decay in fish. The rate of the $\mathrm{pH}$ reduction depending on the number of initial glycogen contained in muscles.

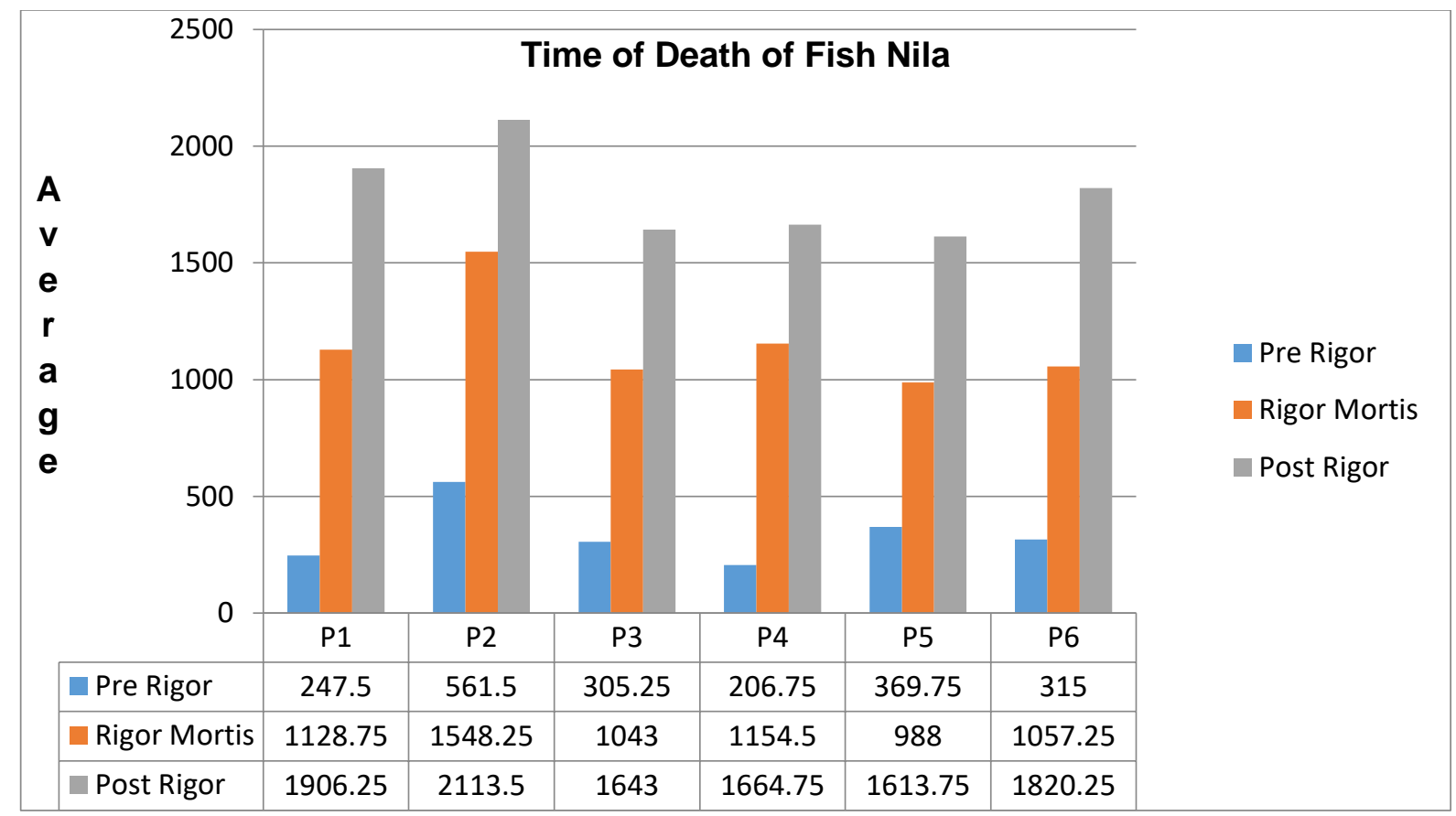

Figure 1: Graph setback Quality fish Nila

Information: $\quad \mathrm{P} 1=$ Left alone, $\mathrm{P} 2=$ Stabbed medulla oblongata $\mathrm{P} 3=$ Spinal broken $\mathrm{P} 4=$ Given freshwater ice P5 =Smeared with kluwak P6 Beaten with hard objects

\section{The pH Value}

The $\mathrm{pH}$ value can be used to determine the level of freshness of the fish. Of 6 treatments are used obtain the same $\mathrm{pH}$ range, namely for the phase of pre-rigor obtained neutral $\mathrm{pH}$ is the average range of 6.81 to 7.16. For rigor mortis phase $\mathrm{pH}$ obtained with an average range of 6.40 to 6.55 . And for $\mathrm{pH}$ with a $\mathrm{pH}$ of post rigor obtained the average range of 7.27 to 7.71 . $\mathrm{PH}$ value charts can be seen in Figure 2. 


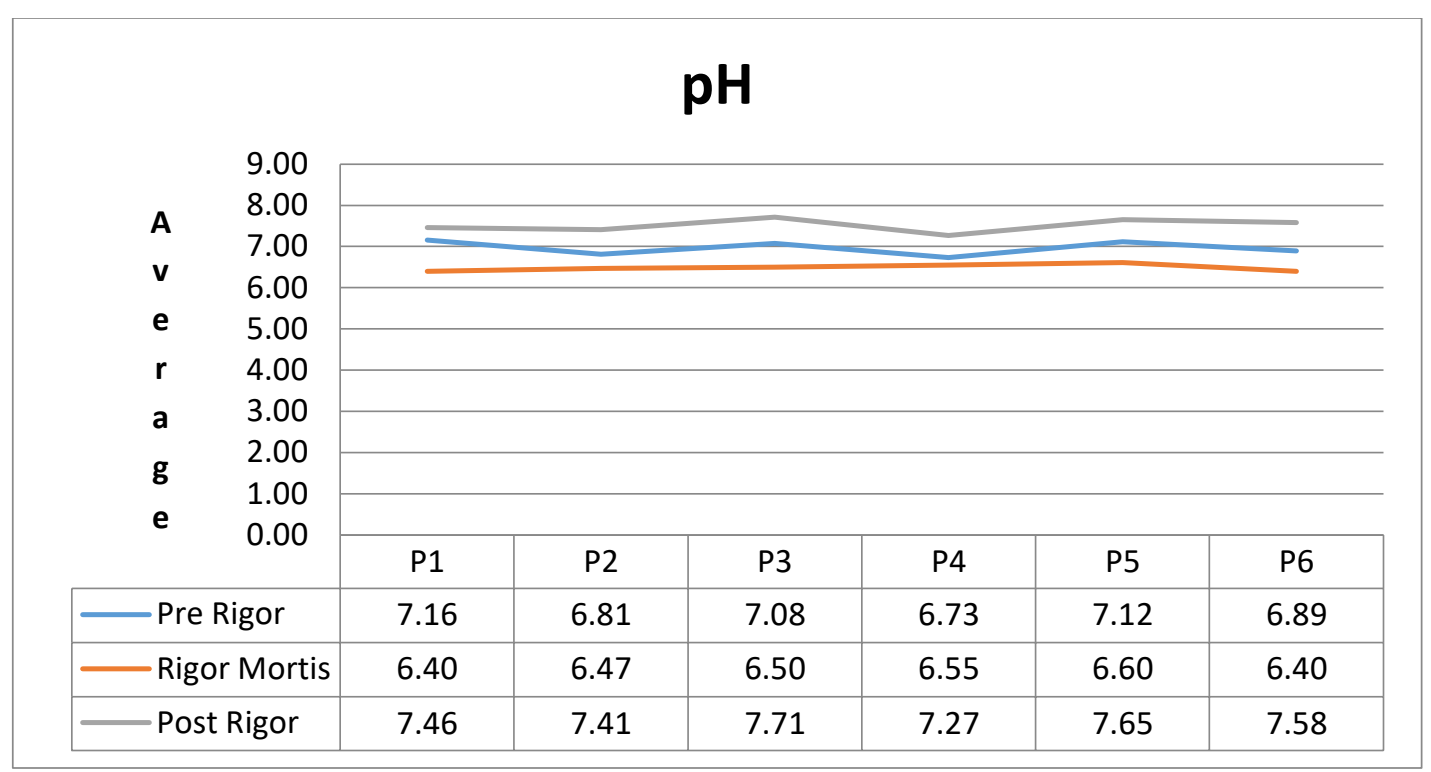

Figure 2: Graph The $\mathrm{pH}$ value

Information: $\quad \mathrm{P} 1=$ Left alone, $\mathrm{P} 2=$ Stabbed medulla oblongata $\mathrm{P} 3=$ Spinal broken $\mathrm{P} 4=$ Given freshwater ice P5 =Smeared with kluwak P6 Beaten with hard objects

The $\mathrm{pH}$ Value is a parameter that can be used to determine the level of freshness of fishery products. Based on the $\mathrm{pH}$, can be determined whether the fish meat is still in the phase or phases of post rigor mortis rigor (Liviawaty and Afrianto, 2014). According to Zakaria (2008), The freshness of the fish can also be determined by measuring the $\mathrm{pH}$ of fish meat. Lactic acid production from glycolysis results anaerobic after the dead fish will determine the change in $\mathrm{pH}$ in fish flesh. PH value changes in fish depend on various factors such as the type of fish, how to catch, feeding and other conditions. Munandar et al., (2009), adding that the lower the temperature, which is then further inhibited enzyme activity. In the process of glycolysis, the enzyme was instrumental in the formation of lactic acid. This leads to the accumulation of lactic acid to run slower so that a decrease in $\mathrm{pH}$ fish also are slower. In addition, the decomposition of protein into compounds that are alkaline by bacteria also inhibited so that an increase in the $\mathrm{pH}$ of the fish are slower. Glycogen massively overhauled and very responsible for the formation of lactic acid meat, causing a decrease in $\mathrm{pH}$ that occurs in the muscles post-mortem. Therefore, glycogen is ultimately responsible for the changes in the properties of the meat accompanying the decrease in $\mathrm{pH}$ with continued glycolysis (Dewi, 2012).

\section{Conclusion}

The treatment effect way to fish kills was not significantly different with the long time quality deterioration of fish. The best treatment of 6 treatments there is treatments by plugging in the medulla oblongata with the results of post rigor longest time compared with other treatments.

\section{References}

[1] Dewi, S. H. C. 2012. Korelasi Anatara Glikogen, Asam Laktat, pH Daging Dan Susut Masak Daging Domba Setelah Pengangkutan. Jurnal AgriSains. 4(5): 59-70. 
[2] Jayanti, S., M. Ilza dan Desmelati. 2012. Pengaruh Penggunaan Minuman Berkarbonasi Untuk Menghambat Kemunduran Mutu Ikan Gurami (Osphronemus gouramy) pada Suhu Kamar. Jurnal Perikanan dan Kelautan. 17 (2): $71-87$.

[3] Liviawaty, E. dan E. Afrianto. 2014. Penentuan Waktu Rigor Mortis Ikan Nila Merah (Oreochromis Niloticus) Berdasarkan Pola Perubahan Derajat Keasaman Jurnal Akuatika. 5(1): 40-44.

[4] Munandar, A., Nurjanah, dan M. Nurilmala. 2009. Kemunduran Mutu Ikan Nila (Oreochromis niloticus) Pada Penyimpanan Suhu Rendah Dengan Perlakuan Cara Kematian Dan Penyiangan. Jurnal Teknologi Pengolahan Hasil Perikanan Indonesia. XI (2): 88-101.

[5] Nazir, M., 2005. Metode Penelitian. Ghalia Indonesia. Bogor. Hal. 58-59.

[6] Nurjanah., I. Setyaningsih., Sukarno, dan M. Muldani. 2004. Kemunduran Mutu Ikan Nila Merah (Oreochromis sp.) Selama Penyimpanan Pada Suhu Ruang. Buletin Teknologi Hasil Perikanan. VII (1): 37-43.

[7] Nurjanah., T. Nurhayati, dan R. Zakaria. 2011. Kemunduran Mutu Ikan Gurami (Osphronemus gouramy) Pasca Kematian Pada Peyimpanan Suhu Chilling. Jurnal Sumberdaya Perairan. 5 (2): 15-18.

[8] Reo, Albert R. 2010. Pengaruh Beberapa Cara Kematian Ikan Terhadap Mutu Ikan Kakap (Lutjanus Sp.). Jurnal Perikanan dan Kelautan Tropis. 6(3): 145-148.

[9] Suprayitno, E. 2016. Dasar Pengawetan. Malang. UB Press.

[10] Zakaria, R. 2008. Kemunduran Mutu Ikan Gurami (Osphronemus gouramy) Pasca Panen pada Penyimpanan Suhu Chilling. Skripsi. IPB: Bogor.

*Corresponding author.

E-mail address: eddysuprayitno88@ gmail.com 